PAULA BALDWIN LIND

Universidad de los Andes, Chile

e-mail: pbaldwin@uandes.cl

\title{
Translating Shakespeare, Translating Culture: Text, Paratext, and the Challenges of Recreating Cultural Meanings in Text and on Stage
}

\section{Abstract}

Translating a Shakespearean play into Spanish - whether that spoken in Spain or in Latin America - constitutes a complex process, as most translators reckon that the semantic transfer is especially challenging, not only because of the syntactic and linguistic differences between the source and the target language, but also because the English text belongs to a context that is geographically and culturally distant, especially in the case of Chile. In addition, due to the fact that Shakespearean texts are scripts to be performed, translators need to consider theatrical elements inherent in the dramatic text that go beyond the textual apparatus, and that may complicate their work. Taking The Tempest, translated into Spanish by two Chilean scholars in 2010, in this article I will argue that a successful translation of Shakespeare for the stage a text that goes from the inter-lingual re-writing of the text to a cultural re-interpretation that speaks to a diversity of contemporary identities and audiences - should endeavour to be cultural, spatial, and collaborative; that is to say, that the translator should have a deep understanding of Elizabethan cultural elements that can be included in the translated text by means of paratexts - precise, relevant, and explanatory linguistic and historical notes that may shed light on directorial decisions once the play is performed, as well as consider the space where the play will be staged, and develop a collaborative system of work with translators, directors, and actors during the whole process.

Keywords: Shakespeare, translation for the stage, cultural elements, The Tempest.

\section{Preliminary ideas}

Translating for the stage constitutes a complex process, as enunciating a script does not only involve conveying the specific sense of words, but also the fact that these words will be, according to Patrice Pavis, "presented by the actor in 
a specific time and space, to an audience receiving both text and mise en scène". ${ }^{1}$ In this brief statement, the critic points out the link between text and performance that has been at the centre of theoretical debate on theatre translation for years. Furthermore, Pavis considers translators as "mediators between two unknown contexts of performance: the «original situation of enunciation» (which might be historically or geographically distant), and the yet-to-be-devised mise en scène in the target culture".

When Susan Bassnett started analysing the problems of translating for the theatre in the 1980 s, she argued that translators should recognize an "ideal performance" in the source text, so as to decode and recode it in the target text. ${ }^{3}$ However, in her later research, she advocates a quite opposite approach to theatre translation: "What is left for the translator to do is to engage specifically with the signs of the text: to wrestle with the linguistic units, the speech rhythms, the pauses and silences, the shifts of tone or of register, the problems of intonation patterns: in short, the linguistic and paralinguistic aspects of the written text that are decodable and reencodable". ${ }^{4}$ To a certain extent, Bassnett leaves the task of integrating text and performance signs to the director rather than to the translator, or at least, leaves the translation/adaptation for the stage for a later stage.

In a similar way to that probably chosen by Shakespeare when writing his scripts, the translator's work consists, in part, in preparing the raw material for performance. Textual translation is the first stage of a dynamic process of consecutive translations and adaptations. Shakespeare, as playwright and poet, initiated the creative process of engendering the text, and, as a director, was also present at the moment of the further translation or adaptation for the stage. In Chile, translators usually submit the first translation or raw material to a publishing house, and if this publication is selected for performance, they are seldom present at the second phase, working side by side with the theatre director and his/her company, unless they have been commissioned to prepare a script for a company or theatre, as in the case of Pablo Neruda and Nicanor Parra, who translated Romeo and Juliet ${ }^{5}$ and King Lear ${ }^{6}$ for

P. Pavis, Problems of Translation for the Stage: Interculturalism and Post-modern Theatre, transl. L. Kruger, in: The Play out of Context: Transferring Plays from Culture to Culture, H. Scolnicov, P. Holland (eds.), Cambridge 1989, p. 25.

2 Eadem, Theatre at the Crossroads of Culture, London 1992, p. 137.

3 S. Bassnett, An Introduction to Theatre Semiotics. Finding a New Language for the 'Language' of Theatre, "Theatre Quarterly" 1980, vol. 10, no. 38, p. 124.

${ }_{4}$ Eadem, Still Trapped in the Labyrinth: Further Reflections on Translation and Theatre, in: Constructing Cultures: Essays on Literary Translation, S. Bassnett, A. Lefevere (eds.), Clevedon 1998, p. 107.

5 Eugenio Guzmán, director of the Theatre Institute at the University of Chile, asked the poet to translate this Shakespearean tragedy in 1963/64. The text was published by Losada in 1964 and staged at the Antonio Varas Theatre that same year, with Diana Sanz and Marcelo Romo playing the leading roles. All the previous translations had been written in prose; Neruda translated the tragedy in hendecasyllabic verse (11 lines).

6 Raúl Osorio, former lecturer at the School of Drama from the Catholic University of Chile, commissioned Nicanor Parra to translate King Lear for the stage in 1991. The poet wrote a free version called Lear Rey \& Mendigo (edited in 2005 by Ediciones Universidad Diego Portales, Chile). It was staged in 1992 keeping the Shakespearean title: El Rey Lear (King Lear). 
specific productions in 1964 and 1992 respectively. This fact introduces relevant variables to the kind of texts that Chilean translators finally produce, since, when they start translating, they usually do not know whether the text will be used for performance or not. Reba Gostand refers to this translation dynamism when she explains that "Drama, as an art form, is a constant process of translation, from original concept to script (when there is one), to producer's/director's interpretation, to contribution by designer and actor/actress, to visual and/or aural images to audience response $[\ldots]$. There may be a series of subsidiary processes of translation at work". 7

Despite the contextual facts already mentioned, the translation of Shakespeare's plays should always endeavour to be cultural, spatial, and collaborative, even when the text is not written for a specific staging. Its performative potential cannot be overlooked or denied, because that is precisely what defines it. Therefore, the translator should imagine how individual words and verses will be delivered by actors onstage, and so take into account not only their meaning and literal sense within the play, but also their rhythm and musicality. The awareness of working with a theatrical script, as Rex Gibson states, "suggests a provisionality and incompleteness that anticipates and requires imaginative, dramatic enactment for completion. A script declares that it is to be played with, explored, actively and imaginatively brought to life by acting out". ${ }^{8}$

Taking The Tempest - a version co-translated into Spanish by Paula Baldwin Lind and Braulio Fernández Biggs in 2010 - as a case study, I aim to show how the knowledge of Elizabethan culture and theatre dynamics, expressed through the inclusion of some notes in the text, may widen the interpretative choice of the translator and the theatre director, as well as the development of a collaborative working system, aspects that may both become key elements in the process of translation for the stage.

\section{Translation of cultural elements}

"Culture" is a broad and complex term. Although my objective is not to define the multiple connotations of this notion here, I will point out the dimensions of culture that may be relevant when analysing the examples in the selected play. "Culture" comes from the Latin term cultura, meaning "the action or practice of cultivating the soil". ${ }^{9}$ During the sixteenth century, this late Middle English idea of tilling the land was figuratively transferred to the "cultivating or development (of the mind, faculties, manners, etc.)". ${ }^{10}$ Later, around 1871, as E.B. Tylor explains, "Culture or Civilization, taken in its wide ethnographic sense, is that

7 R. Gostand, Verbal and Non-verbal Communication: Drama as Translation, in: The Language of Theatre. Problems in Translation and Transposition of Drama, O. Zuber (ed.), Oxford-New York 1980, pp. 1-9. The author is quoted in A. Peghinelli, Theatre Translation as Collaboration: A Case in Point in British Contemporary Drama, "Journal for Communication and Culture" 2012, vol. 2, no. 1, p. 21.

8 R. Gibson, Teaching Shakespeare, Cambridge 1998, pp. 7-8.

9 OED, culture. n., 2.a.

10 OED, culture, 4. fig. 
complex whole which includes knowledge, belief, art, morals, law, custom, and any other capabilities and habits acquired by man as a member of society". ${ }^{11}$

To these definitions, we may add T.S. Eliot's idea of culture, because this critic incorporates the popular dimension, which is often present in Shakespeare's plays. In Notes Towards the Definition of Culture, he suggests that culture can be situated in refinement, learning and the arts, yet not in "any one of these perfections alone". ${ }^{12}$ Thus, we should look for culture "in the patterns of society as a whole". ${ }^{13}$ What Eliot means is not a socially inclusive concept, but the idea that any definition of culture should be broad. There is not one unified culture; the notion entails a definition that is made of a variety of elements, such as persons, buildings, music, historical events, and so forth. It is a combination of the ordinary or banal and the sublime. Culture is therefore not necessarily the best of human creative endeavours; it can be found in everyday activities, as well as in long-standing traditions.

It is precisely because Shakespeare lived and wrote during a specific socio-historical and cultural moment that it is fundamental to understand the elements that fashioned Elizabethan culture. To a certain extent, his plays are not isolated artistic entities, but cultural products immersed in a context that, in turn, functions as a referent for meaning. Cultural elements are not only present in all of Shakespeare's works, but they also contribute to their overall interpretation. According to Peter Newmark, cultural terms are "token-words which first add local colour to any description of their countries of origin, and may have to be explained, depending on the readership and the type of text". ${ }^{14}$ These terms, he argues, pose difficult problems when translating, because it is often impossible to find the equivalent term or sense of the expression. In addition, linguistic systems are different and the meanings of words associated with culture, which work in one language, usually do not work in the other. Thus, translators sometimes use more general or neutral terms to express a similar meaning or replace the original cultural element for another that is part of the target culture.

In a strict sense, translating is always a cultural activity. Michael Neill points out that translation entails "trading between cultures, between different ways of imagining the world, involving both diachronic shifts and delicate synchronic adjustments". ${ }^{15}$ Years earlier, Pavis had also associated the art of translating with an "intercultural practice [that] primarily involves a transfer of culture, in both

11 E.B. Tylor, Primitive Culture: Researches into the Development of Mythology, Philosophy, Religion, Art, and Custom, London 1871, p. 1, quoted in: L. Campillo Arnaiz, Estudio de los elementos culturales en las obras de Shakespeare y sus traducciones al español por Macpherson, Astrana y Valverde, Unpublished PhD thesis, Murcia 2005, p. 94; https:/digitum.um.es/xmlui/bitstream/10201/178/1/LCampilloArnaiz.pdf (access: 16.04.2018).

12 T.S. Eliot, Notes Towards the Definition of Culture, London 1948, p. 23.

13 Ibid.

14 P. Newmark, Approaches to Translation, Oxford 1981, p. 82.

15 M. Neill, The World Beyond: Shakespeare and the Tropes of Translation, in: Putting History to the Question: Power, Politics, and Society in English Renaissance Drama, New York 2000, pp. 399-418, p. 400. The author is quoted in: T. Hoenselaars, Introduction, in: Shakespeare and the Language of Translation, idem (ed.), London 2012, pp. 1-30. 
its textual and its gestural codes". ${ }^{16}$ Commenting on Pavis's theories of translation, Margherita Laera states that by "construing theatre translation as a necessary yet paradoxical task, Pavis suggests the image of the translator as a bridge between two unmapped lands". ${ }^{17}$ In a similar line of thought, Marta Gibińska discusses the notions of "boundary" and "bridge" by applying them to the field of translation and analysing the ways through which a reader of Shakespeare in the language of the playwright may be bound to his/her own culture, whereas a translation of that text into another language does not only open the possibility of survival of that work, but also fosters new readings and interpretations; that is to say, it may build bridges between two different cultures. According to her, "part of the problem of otherness and sameness is the bridge of translation, which means access to both kinds of texts", ${ }^{18}$ although she makes it clear that she is not asking readers to learn two different languages to understand Shakespeare's works better. On the contrary, the scholar argues that the translation of cultural elements should be possible, even if cultural terms are not equivalent, because "translation does not change everything. When laughing at Bottom's translated looks or watching Hamlet's protestations, we can still understand enough to be able to discuss, agree with, or disagree on the issues that the original and the translated texts offer". ${ }^{19}$ Furthermore, her own perspective builds bridges between Shakespeare translators, since she demonstrates how "translators over the ages have proved to what extent foreign languages and cultures are hospitable to Shakespeare" ${ }^{20}$ Finally, in her article on Shakespeare translation, Inga-Stina Ewbank develops the idea of translation as a task that becomes a beneficial cultural exchange, thus reinforcing the possibilities of translating the playwright's works without eliminating cultural elements, but rather adjusting them to another cultural context. ${ }^{21}$

\section{Case study}

In September 2010, Paula Baldwin Lind and Braulio Fernández Biggs, Chilean translators, wrote the first national translation of La tempestad into Spanish, which was published by Editorial Universitaria, a prestigious academic publisher. The following year, the text was adapted by its own translators and was staged by students of the Academy of Scenic Arts at Universidad de los Andes in Santiago, Chile. The source text for the first translation was the 1623 Folio as presented in

16 P. Pavis, Theatre at the Crossroads of Culture, London 1992, p. 137.

17 M. Laera, Theatre Translation as Collaboration: Aleks Sierz, Martin Crimp, Nathalie Abrahami, Colin Teevan, Zoe" Svendsen and Michael Walton discuss Translation for the Stage, "Contemporary Theatre Review" 2001, vol. 21, no. 2, p. 213.

18 M. Gibińska, 'Bottom thou Art Translated': Translation as a Boundary and a Bridge, in: Shakespeare without Boundaries: Essays in Honor of Dieter Mehl, Ch. Jansohn, L. Cowen Orlin, S. Wells (eds.), Newark 2011, p. 289.

19 Ibid.

20 Ibid., p. 286.

21 I.-S. Ewbank, Shakespeare Translation as Cultural Exchange, "Shakespeare Survey" 1995, vol. 48 , pp. $1-12$. 
the Vaughans' Arden Third Series edition of 1999 (reprinted in 2006). The translation was adapted for performance in 2011 by cutting a number of episodes, but the Shakespearean use of verse and prose was preserved, although it was not transferred into an equivalent Spanish metrical system. Incidental music and songs were especially composed for the production and sung with a live orchestra, with a circus-like staging and design, and actors doing acrobatics and choreographies. Despite the colourful and attractive production, critics agreed that its success was due to the language of Shakespeare - translated, but not modified in its poetic basis, and the human message of forgiveness the play discussed in depth. ${ }^{22}$

Going back to the first stage of the process: the translation for publication, one of the most difficult tasks that Baldwin and Fernández faced, was the adequate transfer of early modern cultural elements to the Spanish version of the play. The source text was written many centuries ago in a language whose idiomatic expressions, spelling, and socio-historical context - all elements that contribute to the construction of meaning - have evolved. Translating into Spanish was especially complex when dealing with puns, popular beliefs and proverbs or sayings, and with the characters' different linguistic accents; Elizabethan traditions, names of food, garments, and trades that no longer exist, or measures that are not used at present even in the source culture were also challenging elements. In addition to the technical translation strategies of borrowing, adaptation, explanation, generalisation, literal translation, and reduction ${ }^{23}$ that the translators applied for some of these cases, they decided to explain the cultural terms by means of brief, but complete linguistic, historical, and contextual notes, where both readers and actors could find information meant to help them to understand and interpret the words or expressions that have no exact equivalent in the Chilean culture. Despite the opinion of most scholars that a translation for the stage should function without annotations or theatrical commentary, the Chilean translators of The Tempest decided to include paratexts in the first stage, so as to facilitate the understanding of cultural elements. When the play was adapted for the stage, these notes were left out, but the whole team: translators, directors, producer, actors, and actresses (during seminars of text analysis) read them and used them before rehearsals began. To an extent, paratexts had their own timing within the whole process of translation.

Shakespeare's plays have been translated and edited in most languages. The playwright has undoubtedly become a cultural icon, whose plays and poems are constantly being reinterpreted and recreated on the page and on the stage. His texts are appropriated by translators and editors, who, regardless of their efforts to remain faithful to the "original text", ${ }^{24}$ are forced to rewrite his work and make

22 Cf. reviews: http://diario.elmercurio.com/detalle/index.asp?id=\{9c6bad11-6576-4f38-b2c6450c385c2066 $\}$; http://diario.elmercurio.com/detalle/index.asp?id $=\{71 \mathrm{~cd} 2 \mathrm{~d} 00-\mathrm{b} 863-4 \mathrm{f} 7 \mathrm{e}-\mathrm{affa}-$ f51d963bcbb1\}

${ }^{23}$ A. Fernández Guerra, Translating Culture: Problems, Strategies and Practical Realities, "SIC, A Journal of Literary Translation, Art and Subversion" 2012, vol. 1, no. 3, p. 5.

24 When I speak about "original text", I simply refer to the First Folio of 1623. However, Shakespearean textual scholars admit that the Folio is not necessarily Shakespeare in his original version. 
choices in order to become meaningful to contemporary readers and audiences, so much so that either editing or translating has become a synonym of choice and, in that sense, of the exercise of authority when dealing with the playwright's works.

Evidently, textual authority lies firstly in the author, yet also in the translator in collaboration with other translators, theatre directors, and actors, especially through the choices they need to make during the process. Collaboration here refers to a direct or virtual dialogue in which translators should listen to the author and deal with the text ad mentem auctoris; that is to say, making the effort to express as much as possible what the author of the source text intended to say and being always supported by an informed choice, a term that comes from social and health care, an extra-literary discipline. In the case of Shakespearean editions and translations, it presupposes, as I suggested at the beginning of this article, the knowledge of the cultural context of Elizabethan drama, of Shakespeare's language and poetics, and the ability to collate and compare different editions in order to gather the information necessary for taking editorial decisions. As Stanley Wells argued in one of the lectures given at the Folger Shakespeare Library in Washington D.C. in 1984, editing is not only a matter of presentation, but also of meaning, of establishing Shakespeare's text. Moreover, the critic insists that even though these issues may seem superficial,

they deserve more thorough consideration than they have received, and that such consideration may have consequences of no less importance than those resulting from analyses of the work of individual compositors, investigations of the kinds of manuscript underlying the early printed texts, and other bibliographical and textual techniques to which more attention has been paid in recent years. ${ }^{25}$

When translating Shakespeare, informed choice is directly related both to the election of words and accurate expressions in the target language, and to the addition of paratexts, mainly notes, that guide the modern reader throughout his/her journey into the world of each of the plays and help theatre directors at the moment of recreating that world in the same or in another cultural context.

Notwithstanding that the presence of paratexts could sometimes force the reader to focus on specific elements of the text or influence his/her interpretation of it, their purpose in translations should be to offer the reader access to linguistic, historical, and cultural information that may facilitate his/her reception and understanding of the play. As Gérard Genette states, "more than a boundary or a sealed border, the paratext is rather a threshold, or - a word Borges used apropos

Instead of speaking about an "original text" in the case of translations/editions of Shakespeare, I prefer to refer to a "source text". Despite the fact that textual studies have demonstrated that there is no evidence to prove that the copies the publishers used were manuscripts from Shakespeare, shortly after Blount and Jaggard entered the final copy of the plays in the Stationers' Register, the First Folio of 1623 was published: Mr. William Shakespeare's Comedies, Histories \& Tragedies. According to John Jowett, it became a revolutionary printing endeavour that made available most of the author's works for the first time in one volume (see: J. Jowett, The First Folio, in: Shakespeare and Text, Oxford Shakespeare Topics, Oxford 2007, pp. 69-92).

25 S. Wells, Re-editing Shakespeare for the Modern Reader [electronic resource]: Based on Lectures Given at the Folger Shakespeare Library, Washington D.C., Oxford 1984, p. 1. 
of a preface - a «vestibule» that offers the world at large the possibility of either stepping inside or turning back" ${ }^{26}$ In other words, readers can take advantage of them when they need contextual or extra textual elements for a more pertinent reading. Paratexts in a translation should be an invitation, not an imposition, yet considering that Shakespeare's plays were written more than four hundred years ago within a distant and different cultural background, and in an English that might be alien even to native speakers today, paratexts can certainly become a compass to "travel" across the translated text.

The first Chilean translation of The Tempest (La tempestad) by Baldwin and Fernández, which includes a critical introduction and notes, may be considered as the raw material for performance, in Peter Blayney's view. The British bibliographer analysed the First Folio of Shakespeare in detail and declared: "the author's final draft is essentially only the raw material for performance". ${ }^{27}$ This first created or translated text constitutes the raw material for the stage adaptation and fulfils a similar function to that assigned by Andrew Gurr to the "maximal" texts that theatre companies owned: "the original company's own written playbook" versus "the texts players performed" 28 or "minimal" texts. Regarding these different scripts, the early modern scholar explains that "the authoritative written text was designed from the outset to be an idealized text, and that every one of the early performances altered it into more realistic or realisable shapes, often at a quite drastic remove from the ideal". ${ }^{29}$

Authors such as Mona Baker, David Katan, Roberto Mayoral, Lucía Molina, Peter Newmark, Sergei Vlakhov and Sider Florin ${ }^{30}$ have classified cultural aspects involved in translation. Based mainly on Newmark (1988), ${ }^{31}$ who follows Eugene Nida (1964), Laura Campillo Arnaiz ${ }^{32}$ creates her own taxonomy of cultural elements in the study of Shakespeare's plays that includes: food and drinks, clothes and fabrics, measurements, coins, locations, trades, games, laws, folk beliefs, references to people, and literary references. For the purpose of my analysis, I will select some of these and suggest ways in which they can be translated into Spanish, taking La tempestad as a sample.

26 G. Genette, Paratexts: Thresholds of Interpretation, J.E. Lewin (trans1.), Cambridge 1997, p. 1.

27 P. Blayney, The First Folio of Shakespeare. The Norton Facsimile, $2^{\text {nd }}$ edn. New York-London 1996, p. xxx, quoted in: A. Gurr, Maximal and Minimal Texts: Shakespeare v. the Globe, "Shakespeare Survey", vol. 52, S. Wells (ed.), Cambridge 1999, p. 69.

28 A. Gurr, op. cit., p. 70.

29 Ibid.

30 These are the texts mentioned by Fernández Guerra, p. 2: M. Baker, In Other Words. A Coursebook on Translation, London 1992; D. Katan, Translating Cultures. An Introduction for Translators, Interpreters and Mediators, Manchester 1999; R. Mayoral Asensio, La explicitación de la información en la traducción intercultural, in: Estudis sobre la traducció, ed. A. Hurtado Albir, Castellón 1994, pp. 73-96; L. Molina Martínez, Análisis descriptivo de la traducción de los culturemas árabe-español, $\mathrm{PhD}$ diss. Universitat Autónoma de Barcelona 2001; S. Vlakhov, S. Florin, Neperovodimoe v perevode. Realii, "Masterstvo perevoda" 1970, vol. 6, Moskva, Sovetskij pisatel, pp. 432-456.

31 Newmark establishes five categories of foreign cultural words: ecology, material culture, social culture, organizations, customs, activities, procedures or concepts, gestures and habits. See: P. Newmark, A Textbook of Translation, London-New York 1988, p. 21.

32 L. Campillo Arnaiz, op. cit. 


\section{a) Food and drinks that were usually consumed in Elizabethan England}

In the second act of The Tempest, Trinculo finds Caliban and describes him: "A fish: he smells like a fish, a very ancient and /fish-like smell, a kind of - not of the newest/ - poor-John" (2.2.25-27). It would be quite difficult for a modern reader to know what the character is referring to if there's not a note explaining the meaning of "poor-John": dried, or long-dead fish, as the editors of the Arden third series edition point out. This diet was very common among homeless and poor people in early modern England. In Baldwin and Fernández's translation, the solution was to replace the proper name with both an explanatory name and a note:

\begin{abstract}
A fish: he smells like a fish, a very ancient and fish-like smell, a kind of / - not of the newest

- poor-John. A strange fish!
\end{abstract}

\author{
¡Un pez! Huele como a pez; un aroma \\ a pescado rancio, como de merluza salada,/ \\ y no de las más frescas \\ que digamos. ¡Extraño pez!
}

(2.2.25-27, emphasis mine).

The Spanish word merluza in the text becomes the cultural, not literal, translation of the expression "poor-John", since a Chilean audience will be familiar with the characteristics of this fish, which are similar to the ones described by Trinculo. Then, its meaning was explained in a brief note: "Se llamaba poor-John a la merluza seca y salada, dieta bastante común entre los más pobres de aquella época". ${ }^{33}$ These lines could be back-translated in the following way: poor-John is the name of dry and salty hake. It was quite a common diet among the poor at that period in England.

If the text is adapted for performance, directors and actors could look for an equivalent expression or should try to show a similar dish or food onstage. In Chile it would probably be merluza, one of the most traditional species in the country, ${ }^{34}$ or jurel, a very cheap tinned fish with a strong smell.

\section{b) Clothes and fabrics that generally identify people's status and/or trade}

In the third act, when Ariel speaks in Trinculo's voice, calling Caliban a liar, the monster asks: "What a pied ninny's this? Thou scurvy patch!" (3.2.61): "iQué tonto colorinche es éste! ¡Tú, patético bufón!” (What a silly colourful thing this is, you pathetic fool!). ${ }^{35}$ Again the Arden editors provide some information in note 61 , in which they explain that pied ninny ("tonto colorinche") is a "reference to the jester and his costume", ${ }^{36}$ a parti-coloured garment, which in this case is worn by Trinculo. Unfortunately, real jesters have disappeared from our society. Moreover, there is no tradition of jesters in Chile, at least not in a strict sense, so the translators of the play needed to include a note with a clear description of his

33 Paula Baldwin Lind and Braulio Fernández Biggs, transl. William Shakespeare. La tempestad. Santiago (Chile) 2010, p. 83, note 26.

34 This fish is not as cheap now in Chile as it was when first commercialised in the country.

35 P. Baldwin Lind, B. Fernández Biggs, op. cit., p. 97.

36 V. Mason Vaughan, A.T. Vaughan (eds.), William Shakespeare. The Tempest, The Arden Shakespeare, Third Series, London 2006, p. 228. 
clothes: "ropas multicolores utilizadas por un bufón; en este caso, Trínculo"37; that is: very colourful clothes, usually alternating red and yellow, which Trinculo wears as a jester. Nevertheless, the local character that would be more similar to a jester, would be a payador, a kind of folk-song singer, who usually plays with words, making fun of people and situations; or a payaso, a character that is similar to a clown and is linked to a circus-like culture.

A theatre director or the costume designer could decide to dress the actor/actress in garments that identify this character with a more Chilean tradition, but this would depend on the type and context of the performance. For the 2011 staging at Universidad de los Andes (Chile), Trinculo was dressed as a traditional European jester and the audience was captivated by his somersaults, cabrioles, songs, and sense of humour, thus showing that the notion of "jester" was culturally more universal onstage than the translators thought after the first translation of these lines of the play.

\section{c) Measurements, specifically those related to the division and length of time}

Particularly in the case of The Tempest, the passing of time is crucial to the quick development of the plot and Prospero's final act of forgiveness. In this romance, Shakespeare adheres to the unity of time and compresses the events to one afternoon. The problem for a cultural translation is that the characters measure time in a very specific way, following the codes used by sailors during the Elizabethan period.

In the second scene of the first act, Prospero asks Ariel for the time of the day and the spirit replies: "Past the mid-season" (1.2.239). The magician amplifies Ariel's time when he adds: "At least two glasses" (1.2.240). Apart from explaining that early modern sailors usually measured time using half-hour glasses, Baldwin and Fernández preferred to avoid a literal translation, which would have been either: "Al menos la medida de dos relojes de arena" (At least the measurement of two hourglasses), or "Al menos la medida de dos vasos" (At least the measurement of two glasses). Instead of choosing the literal translation of this expression, they preferred to refer to time in a direct way, so as to make it more understandable: "Dos horas más, a lo menos" (At least two more hours, 1.2.240). The note in the text explains: "At least two glasses: expresión que alude a la medida de los relojes de arena. A diferencia de la media hora por ampolleta que utilizaban los marineros, cada lapso equivale aquí a una hora. Por tanto, si se suman two glasses al tiempo indicado por Ariel, serían exactamente las dos de la tarde". ${ }^{38}$ In a back-translation it would read as follows: "At least two glasses": expression that refers to the measurement of time with hourglasses. Unlike the half hour per glass used by sailors, each lapse is equivalent to one hour here. Therefore, if two glasses are added to the time indicated by Ariel, it would be exactly two o'clock in the afternoon. An actor onstage could say "two hours at least" and show either an hourglass or any other local objet related to time; nevertheless, this choice would result from a previous

37 P. Baldwin Lind, B. Fernández Biggs, op. cit., p. 97, note 61.

38 Ibid., p. 56, note 240. 
discussion and consensus decision of the whole team - translator, theatre director, and company - regarding the symbolism and relevance of time within the play.

d) Popular beliefs, either related to religious matters or superstitions, as well as local traditions

In the scene discussed in letter a), when Trinculo meets Caliban in Act 2, he wonders: "Were I in England now (as/once I was) and had but this fish painted $[\ldots]$ " (2.2.27-28, emphasis mine). The expression "a fish painted" would not mean much to a Chilean or Latin American audience, apart from the literal sense: "un pez pintado" (a fish that is painted), simply because this is not part of our cultural context. The Arden note explains that products were "painted on a sign to attract the notice of passers-by" (note 28). The Chilean translators changed the verb tense to the Spanish imperfect subjunctive, ${ }^{39}$ as marked in bold letters in the following line: "Si estuviera ahora en Inglaterra /(como en cierta ocasión) e hiciese pintar este pez [...]" (2.2.27-28). The back-translation would be: If I were now in England (as/I was in one occasion) and I asked to paint this fish [...]. Then, the translators wrote a note similar to the Arden explanation, yet adding an interpretative comment which are in bold letters in the text to differentiate it from the rest of the information: "Como una forma de publicidad, en la era isabelina se solían pintar diferentes artículos de venta en letreros o carteles, generalmente de madera, para ser colgados tanto fuera de los negocios como a la entrada de las ferias, para atraer así a los clientes. En Londres, las mejores novedades se exhibían en Fleet Street. Al querer pintar a Calibán como un pez, Trínculo pretende mostrarlo como un producto exótico y sacar provecho económico de él" (During the Elizabethan era different items of sale were frequently painted on signs or posters, usually made of wood, to be hung both outside the shops and at the entrance of the fairs, as a form of advertising to attract customers. In London, the best products were sold on Fleet Street. When Trinculo says he wants to paint Caliban as a fish, he tries to present the monster as an exotic product, so as to obtain economic profit out of him).$^{40}$

\section{f) Wordplay, puns, and proverbs}

Wordplay, puns, and proverbs are another vast area of cultural translation, perhaps the most challenging, since transferring comic references, reproducing the phonetics of another language, and finding an equivalent common saying is almost impossible. The Tempest if full of references to proverbs; for example, in 2.2.69: "that ever trod on neat's leather", or "Here / Is what will give language to you, cat" (2.2.81-82). Baldwin and Fernández first explained the original sayings in different notes: "del proverbio As good a man as ever trod on shoe (neat's)

39 The imperfect subjunctive tense is very often used in Spanish. This tense is also known as the Spanish past subjunctive, but its real name is the preterite imperfect tense of the subjunctive mood. The subjunctive does not express time. It reveals the point of view of a speaker.

40 Ibid., p. 53, note 28. The corresponding lines are in bold letters in Spanish and in English. 
leather (as ever went on legs). Alude a utilizar zapatos de cuero, finos y suaves. Para fomentar la industria nacional, los ingleses promovían el uso de cuero de vaca y de este modo relegaban el producto español" (From the proverb As good a man as ever trod on shoe (neat's) leather (as ever went on legs). Alluding to the use of thin and soft leather shoes. To encourage the national industry, the English promoted the use of cowhide and thus relegated the Spanish product $)^{41}$; and "del proverbio Liquor will make a cat speak: "La buena bebida hace hablar hasta a un gato". En este caso, la bebida hará hablar a un monstruo" (From the proverb Liquor will make a cat speak: Good drink makes even a cat speak. In this case, the drink will make a monster speak). ${ }^{42}$ In the first case, the translation of the lines in the play was literal, because the meaning could be well understood and represented by actors: "digno presente/será para cualquier emperador que haya caminado en cueros de/vaca" (worthy present / will be for any emperor who has walked in cowhides; 2.2.68-69). For the second case, the translators resorted to the original proverb and made the connection with the liquor that Stefano gives to Caliban, so that his tongue becomes loose and he can tell them more secrets about the island: "He aquí / lo que te hará hablar, gato" (Here's / what will make you talk, cat; 2.2.81-82). If the actor who delivers these lines shows a bottle of liquor, the audience might understand even better the sense of the whole passage.

\section{Translation as collaboration}

The objective of presenting a few textual examples in the previous section was meant to show that when transferring cultural elements from one language to the other it is always advisable to work collaboratively, since there are relevant semantic and interpretative issues to discuss before deciding how to communicate the culture portrayed in a specific play: either to make the translation mirror that worldview or to transform it into something more familiar to the new readers and audience.

Collaboration in translation does not go against individual creative autonomy; we can take Shakespeare's own experience as a collaborator in twenty per cent of the plays in the Shakespearean canon. ${ }^{43}$ Both for Shakespeare and for other Elizabethan playwrights, as Gary Taylor argues, "collaboration cannot be explained by simple economies of time or personnel. The motive cannot be quantitative. It's not about the numbers. It must be qualitative, and therefore phenomenological. Collaboration in some way improved the quality of the human experience". ${ }^{44}$ Moreover, in the case of translation for the stage, collaboration can be practised at different levels; it does not mean that translators must be forced to work with other translators, which anyway, is a very fruitful exercise; but that at some phase

41 Ibid., p. 85 , note 69.

42 Ibid., notes $81-82$.

43 G. Taylor, Why did Shakespeare Collaborate?, in: Shakespeare Survey, vol. 67: Shakespeare's Collaborative Work, P. Holland (ed.), Cambridge 2004, 1-17, p. 1.

44 Ibid., p. 4. 
in the process of translating, s/he should be able to generate a dialogue with theatre directors, actors, other translators, linguists, and sometimes even historians, if needed, and very often with publishers of the text. As for the last ones, Umberto Eco clearly explains that dialogue should be promoted with them too:

Numerous are the elements that come into play in the process of negotiation; on one side, there is the original text, with its own rights, sometimes an author who claims rights over the whole process, along with the cultural framework in which the original text is born; on the other side, there is the destination text, the cultural milieu in which it is expected to be read, and even the publishing industry, which can recommend different translation criteria, according to whether the translated text is to be put in an academic context or in a popular one. ${ }^{45}$

Consensus in translation should occur at different levels: "a consensus about the nature of the world of the play", ${ }^{46}$ and about the meaning of it. In this way, it will certainly improve the quality of the translator's work and the human experience of the audience when the play is performed. David Johnston highlights the importance of consensus in the process of translation, when he argues that

$[\ldots]$ the collaborative work undertaken by the translator is invariably three-fold: a strategic engagement with the receiving theatre system, from which the translation derives its overall shape and pitch; a simultaneous engagement with both original and new texts that allows the product that emerges from that readerly and writerly doubleness to work on stage, both within the conventions of that system and in response to the contingencies of the theatre event itself; and, of course, a professional engagement with the creative team whose task it is to draw out all the potentials for performance that are encoded within that new text. ${ }^{47}$

Collaborative dialogue and the use of paratexts are not the only elements that translators should take into consideration at the moment of translating Shakespeare for the stage. Taking into account my own research, I argue that when translating for the stage, the notion of space also needs to be considered in the process because plays are written to be performed in specific stages. In fact,

Elizabethan dramatists worked and played with the notion of space when writing their scripts and at the moment of performance so as to create a sense of place and space on page and stage. They probably had in mind the specific characteristics of theatre companies, the type of audience, and the constraints and resources of the stages where their plays were represented. Even though Shakespeare and his playwright-contemporaries shared a set of generic conventions, the ways in which play and space were related in performance varied not only from one playwright to the other, but also from play to play, from season to season, and, certainly, from stage to stage. ${ }^{48}$

45 U. Eco, Saying Almost the Same Thing: Experiences in Translation, Milan 2003, p. 18.

46 M. Laera, op. cit., p. 221. The author follows the opinion of Zoë Svendsen, theatre director, dramatist, and researcher.

47 D. Johnston, Narratives of translation in performance: collaborative acts, in: Adapting Translation for the Stage, G. Brodie, E. Cole (eds.), New York 2017, p. 236.

48 P. Baldwin Lind, The Film Industry Woos Shakespeare: Theatrical Space versus Cinematographic Space in the Adaptations of Hamlet and Henry V by Kenneth Brannagh, in: eadem (ed.), Telling and Re-telling Stories: Studies on Literary Adaptation to Film, Newcastle-upon-Tyne 2016, p. 79. 
The notion of space is definitely bound to culture, and in the case of Shakespearean drama, to a very specific kind of theatrical performance. I am not claiming with this that performances of Shakespeare's plays should imitate early modern staging, but that space as a dramatic category should be especially translated for the stage. In practical terms, this means that the ideal condition for a translator would be to know in advance the characteristics of the stage where the play will be performed in order to be able to adapt the length of verses, so as to make sure that the actor or actress delivering that speech will have enough time to say it if $\mathrm{s} / \mathrm{he}$, for example, has to cross the whole stage.

In the case of La tempestad, space was particularly relevant in the translation, not only because the plot develops in an island (an enclosed space), but also because of the circus-like performance: many characters were doing acrobatics onstage. The case of Ariel was very meaningful in this respect. Being "an airy spirit", ${ }^{49}$ he literally flew all over the stage and even up, when he hung from the stage ceiling, holding to a hoop or rope. These movements did not imply modifications of the text regarding words or expressions, but they did produce changes in rhythm, especially when the character was singing. Baldwin and Fernández introduced a different punctuation than the source text into the Spanish version in order to create the pauses that were necessary to interpret the songs while making acrobatics.

ARIEL (Canta y lo ayuda a vestirse.)

Donde la abeja liba libo yo,

Tendido en una campanilla de primavera:

Allí me escondo cuando los búhos ululan.

Sobre el lomo del murciélago vuelo yo,

Persiguiendo alegremente al verano.

Alegre, alegre viviré ahora,

Bajo las flores que penden de la rama.
ARIEL (Sings and helps to attire him.)

Where the bee sucks, there suck I,

In a cowslip's bell I lie;

There I couch when owls do cry.

On the bat's back I do fly

After summer merrily.

Merrily, merrily, shall I live now,

Under the blossom that hangs on the bough

(5.1.88-94).

The changes in punctuation may seem very subtle in the text, but they respond to the movements of Ariel onstage, to the space the character occupies, and to the musical rhythm and chords.

\section{Conclusion}

The number of examples related to paratexts or to the use of space in the process of translating Shakespearean drama for the stage exceeds the limit of this article. It is clear that translating and editing Shakespeare for the stage is not only a linguistic process, but also a collaborative enterprise, in which many social and cultural agents participate. In terms of the book market, it means that to an extent, each translation of a play is a recreation of the original in another language, and, at the same time, it is a revision of previous translations that constitute a linguistic tradition or history of that play. As Wells claims, "it would, of course, be absurd to

49 V. Mason Vaughan, A.T. Vaughan, op. cit., p. 140. 
suggest that a new edition should be prepared every time someone proposes a new emendation or offers a fresh interpretation of a particular passage. The process is cumulative", ${ }^{50}$ and it is precisely through this process that textual choice and authority are exercised. Once the text is set, theatre directors can make their own choices, so that words are put to action onstage.

Understood in this way, translations may contribute to maintain certain works within the literary canon of each country and its culture, since they keep on being rewritten, and consequently printed, published, and adapted for performance. Translations also widen the scope of the local canons, as they open up the possibility of reading foreign authors in the peoples' native language; moreover, according to Wells, "the editor's most basic task lies in the establishment of a text, editions properly serve many other purposes for a constantly changing readership". ${ }^{51}$ One of these other purposes is the performance of the translated plays. If we want the words we have chosen in translation to be preserved by theatre directors, we need to build a bridge between translators and theatre professionals, so that, out of a fruitful dialogue, more and better translations of Shakespeare can find their place on the stage. In Eco's words, in the process of translating a work of literature into another language, translators should be aware that "even though knowing that one never says the same thing, one may say almost the same thing" 52 ; that "almost" may produce a significant difference between one translation of Shakespeare and another.

\section{References}

Baldwin Lind P., The Film Industry Woos Shakespeare: Theatrical Space versus Cinematographic Space in the Adaptations of Hamlet and Henry V by Kenneth Branagh, in: eadem (ed.), Telling and Re-telling Stories: Studies on Literary Adaptation to Film, Newcastle-upon-Tyne 2016, pp. 79-98.

Bassnett S., An Introduction to Theatre Semiotics. Finding a New Language for the 'language' of Theatre, “Theatre Quarterly" 1980, vol. 10, no. 38, pp. 47-55.

Bassnett S., Still Trapped in the Labyrinth: Further Reflections on Translation and Theatre, in: S. Bassnett, A. Lefevere (eds.), Constructing Cultures, Clevedon 1998, pp. 90-108.

Campillo Arnaiz L., Estudio de los elementos culturales en las obras de Shakespeare y sus traducciones al español por Macpherson, Astrana y Valverde, Unpublished $\mathrm{PhD}$ thesis, Murcia 2005; https://digitum.um.es/xmlui/bitstream/10201/178/1/ LCampilloArnaiz.pdf (access: 16.04.2018).

Eco U., Saying Almost the Same Thing: Experiences in Translation, Milan 2003.

Eliot T.S., Notes Towards the Definition of Culture, London 1948.

Ewbank I.-S., Shakespeare Translation as Cultural Exchange, "Shakespeare Survey" 1995, vol. 48, pp. 1-12.

\footnotetext{
50 S. Wells, op. cit., p. 3.

51 Ibid., p. 3.

52 U. Eco, op. cit., p. 10.
} 
Fernández Guerra A., Translating Culture: Problems, Strategies and Practical Realities, "SIC, A Journal of Literary Translation, Art and Subversion" 2012, vol. 1, no. 3 , pp. 1-27.

Genette G., Paratexts: Thresholds of Interpretation, J.E. Lewin (transl.), Cambridge 1997.

Gibińska M., 'Bottom thou art translated': Translation as a Boundary and a Bridge, in: Ch. Jansohn, L. Cowen Orlin, S. Wells (eds.), Shakespeare without Boundaries: Essays in Honor of Dieter Mehl, Newark 2011, pp. 283-291.

Gibson R., Teaching Shakespeare, Cambridge 1998.

Gostand R., Verbal and Non-verbal Communication: Drama as Translation, in: O. Zuber (ed.), The Language of Theatre. Problems in Translation and Transposition of Drama, Oxford-New York 1980, pp. 1-9.

Gurr A., Maximal and Minimal Texts: Shakespeare v. the Globe, in: S. Wells (ed.), Shakespeare Survey, vol. 52, Cambridge 1999, pp. 68-87.

Hoenselaars T., Introduction, in: idem (ed.), Shakespeare and the Language of Translation, London 2012, pp. 1-30.

Johnston D., Narratives of Translation in Performance: Collaborative Acts, in: G. Brodie, E. Cole (eds.), Adapting Translation for the Stage, New York 2017, pp. 236-249.

Jowett J., The First Folio, in: Shakespeare and Text, Oxford Shakespeare Topics, Oxford 2007.

Laera M., Theatre Translation as Collaboration: Aleks Sierz, Martin Crimp, Nathalie Abrahami, Colin Teevan, Zoë Svendsen and Michael Walton discuss Translation for the Stage, "Contemporary Theatre Review" 2001, vol. 21, no. 2, pp. 213-225.

Neill M., The World Beyond: Shakespeare and the Tropes of Translation, in: Putting History to the Question: Power, Politics, and Society in English Renaissance Drama, New York 2000, pp. 399-418.

Newmark P., Approaches to Translation, Oxford 1981.

Newmark P., A Textbook of Translation, London-New York 1988.

Nida E., Toward a Science of Translating with Special Reference to Principles and Procedures Involved in Bible Translating, Leiden 1964.

Pavis P., Problems of Translation for the Stage: Interculturalism and Post-modern Theatre, L. Kruger (transl.), in: H. Scolnicov, P. Holland (eds.), The Play Out of Context: Transferring Plays from Culture to Culture, Cambridge 1989, pp. 25-44.

Pavis P., Theatre at the Crossroads of Culture, London 1992.

Peghinelli A., Theatre Translation as Collaboration: A Case in Point in British Contemporary Drama, "Journal for Communication and Culture" 2012, vol. 2, no. 1, pp. 20-30.

Shakespeare W., La Tempestad, traducción, introducción y notas by Paula Baldwin Lind and Braulio Fernández Biggs, Santiago 2010.

Shakespeare W., The Tempest, V. Mason Vaughan, A.T. Vaughan (eds.), The Arden Shakespeare, Third Series, London 2006.

Taylor G., Why did Shakespeare Collaborate?, in: P. Holland (ed.), Shakespeare Survey, vol. 67: Shakespeare's Collaborative Work, Cambridge 2004, pp. 1-17.

Tylor E.B., Primitive Culture: Researches into the Development of Mythology, Philosophy, Religion, Art, and Custom, London 1871. 
Wells S., Re-editing Shakespeare for the Modern Reader [electronic resource]: Based on Lectures Given at the Folger Shakespeare Library, Washington D.C., Oxford 1984. 